\begin{tabular}{|c|c|c|c|c|c|c|}
\hline \multirow{4}{*}{ Impact Factor: } & ISRA (India) & $=3.117$ & SIS (USA) & $=0.912$ & ICV (Poland) & $=6.630$ \\
\hline & ISI (Dubai, UAE & $=0.829$ & РИНЦ (Russia) & $=0.156$ & PIF (India) & $=1.940$ \\
\hline & GIF (Australia) & $=0.564$ & ESJI $(\mathrm{KZ})$ & $=8.716$ & IBI (India) & $=4.260$ \\
\hline & JIF & $=1.500$ & SJIF (Morocco) & $=5.667$ & OAJI (USA) & $=0.350$ \\
\hline
\end{tabular}

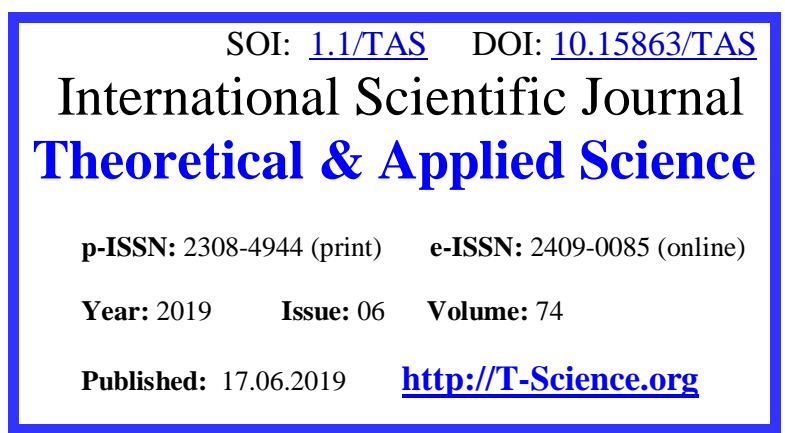

SECTION 11. Biology. Ecology. Veterinary.

UDC: $551.4(338.48)$
QR - Issue
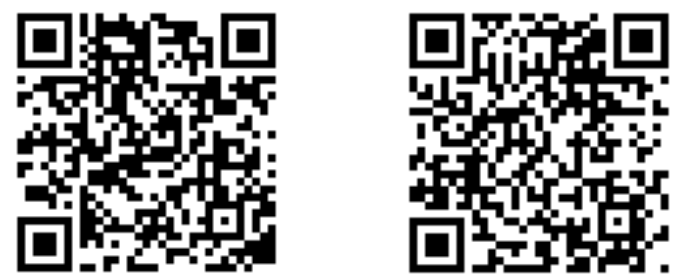

Shokhsanam Toshkanboyevna Yakubjonova Tashkent state pedagogical university named after Nizami Associated professor, $\mathrm{PhD}$ of geography, Uzbekistan

Sayyora Toshpulatovna Artikbaeva Tashkent state pedagogical university named after Nizami

Teacher, Retraining center, Uzbekistan

Nasiba Abdirashid qizi Khakimova Tashkent state pedagogical university named after Nizami 3 rd year student of biology,Uzbekistan

\title{
A SEPARATION OF THE REPUBLIC OF UZBEKISTAN INTO AGROTOURISTIC REGIONS AND USE OF THEM AS A TOURISTIC AIMS
}

Abstract: The article involves the separation of the territory of the Republic of Uzbekistan into agrarian areas for the development of agrotourism. The results of research are directed to define the landscape complexes of agroindustrial potential in different geographical regionalization. A separation of agrotouristic areas requires a variety of factors in the territory of Uzbekistan. Regionalization principles on agrotouristic territories, peculiarities and indicators of agrotourism were described in the article.

Key words: method, agrotourism, regional, landscape, indicator, map, principle, diversity, touristic aim.

Language: English

Citation: Yakubjonova, S. T., Artikbaeva, S. T., \& Khakimova, N. A. (2019). A separation of the republic of Uzbekistan into agrotouristic regions and use of them as a touristic aims. ISJ Theoretical \& Applied Science, 06 (74), 244-247.

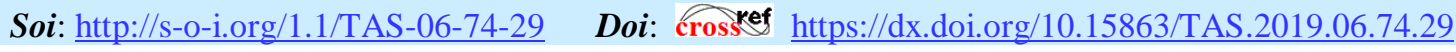

\section{Actuality.}

Regionalization is a universal method of regulating and systematizing the territorial systems which widely used in geography. It plays an important role to solve many geographic problems. L.N Babushkin, N.A.Kogay (1964), P.Baratov (1996), Sh.S.Zokirov, I.Muminov (2004) held a research on the various sphere of the geography in Uzbekistan , as well as A. Soliev, R. Mahamadaliyev (2004), T.Djumaev (2004), I.A.Hasanov (2006), A.N.Nigmatov, N. Shamuratova (2007) conducted the research on tourist zoning.

We have used the results of these regionalization (zoning) trends to separate the territory of Uzbekistan into agrarian regions. In particular, it is important to take into account the territorial differences of the separated landscape complexes in determining of the agroindustrial potentialin different geographical regionalization. We can see that no special studies have been conducted in Uzbekistan for the allocation of agrarian districts. That is why we have analyzed the researches performed on the general zoning of tourism and some of its trends [6; pp.53-54]. For example, E.A. Kotlyarov have based the following indexes such as the health resort and recreational establishments development that representing the specialization of the region in the implementation of recreational zoning, the interaction of production lines with tourist-health-improving enterprises of the given territory and the employment of the population in these farms [2; pp.238]. It was used four-tier taxonomic system units: republic (province, region), district, recreational area, and recreational micro district. Yu.S.Putrik, V.V. Sveshnikov divided the region into zones and districts on touristic zoning [3; pp. 3-13].

According to N. Shamuratov's research, the ecotourism zoning of the territory of Uzbekistan is 


\begin{tabular}{|c|c|c|c|c|c|c|}
\hline \multirow{4}{*}{ Impact Factor: } & ISRA (India) & $=3.117$ & SIS (USA) & $=0.912$ & ICV (Poland) & $=6.630$ \\
\hline & ISI (Dubai, UAI & $=0.829$ & РИНЦ (Russia & $=0.156$ & PIF (India) & $=1.940$ \\
\hline & GIF (Australia) & $=0.564$ & ESJI (KZ) & $=8.716$ & IBI (India) & $=4.260$ \\
\hline & JIF & $=1.500$ & SJIF (Morocco & $=5.667$ & OAJI (USA) & $=0.350$ \\
\hline
\end{tabular}

based on the availability of ecotouristic resources and the possibility of using it in ecotourism [4; pp.70-80].

A separation of agrotouristic areas requires a variety of factors (natural, economic, ecologicalphysiological, historical, agrarian economy, etc.). Such regionalization involves the identification of the potential and opportunity for use in different regions, and which describes the purposeful organization of agrotourism in them. By means of assessment the agrotouristic capacity of regions, a system of the districts with different characteristics will be separated [1; pp.24].

\section{Material and methods.}

The natural and anthropogenic complex was taken as a basis for agrotouristic regionalization of the republic. The existing landscape maps serve as an information base. These allow for the identification of natural components and structures with restrictive or effective indicators.

In agrotouristic regionalization, it is important to take into account the following characteristics of the regions to attracting tourists: 1) diversity of agro landscapes and their level of repetition; 2) the attractiveness, of agrotouristic resources, rare, possibility of earning income; 3) cultural, agrarian and ethnographic values (historical and architectural monuments, centers of agriculture and craftsmanship, presence of ethnographic specific addresses, etc.); 4) availability of public and individually-used natural and agrolandscape areas, and their adaptability and convenience to conduct the holiday for agrotourists.

Taking into account the above-mentioned factors, the separation of the agrotouristic regions can be based on the following principles [5; pp.13-15]:

1. The priority of anthropogenic cultured level of geocomplexes. This principle is important for the territorial organization of agrotourism. Cultural landscapes are anthropogenic landscapes, which is built on the basis of natural resource use and it is directed to satisfy their own needs. Cultural landscape consists of a region; it is similar to natural conditions and resources and which has been used for many years in a particular branch of the economy (for example, in agriculture). Their main peculiarities are measured by fertility and productivity of land and index of economic efficiency of productions. Thus, cultural landscapes are main factors for agrotourism.

2. Complexity - the need to combine the agronomic tourism with other tourism types. It involves the agrotourism, which it consists of historical, pilgrimage, spiritual and ecological tourism. To separate the districts, it is essential to combine the agro tourism with some tourism and it will contribute to its popularity and effectiveness. For example, it is significant to combine the agro tourism with historical tourism in areas with a lot of historical and archaeological monuments and ecological tourism, which natural resources are rich in determined areas.

3. An existence of travel opportunities. Agrotouristic resources, which attractive objects for tourists and existence of usage opportunities are accounted fully to define the agrotouristic districts.

4. Service availability. To use from agrotouristic opportunities of the region in effective organization to accept the agrotourists, to put into place, to organize the restoration and existence of service maintenance for agrotourism are the main factors.

5. The diversity of cultures and their uniqueness. The village life, lifestyle, unique public ceremonies, holidays and festivals determine the uniqueness of the regions and become attraction factor as an integral part of the agrotouristic districts capacity.

We have used the methods of territorial analysis, cartographic, comparative-geographical, analysis of field research, expeditionary, statistical, and typological.

\section{Results and discussion.}

In our research, the following peculiarity and indicators were used as a base to separate the agrotouristic districts:

$>$ an existence of specific agrotouristic potential and capacities of each district;

$>$ an availability of specific agrotouristic objects and their impact to the agrotouristic specialization;

$>$ a compliance of agrotourism with local agricultural production specifics; an aesthetic peculiarities of the regions (attractive objects, landscapes and their comfortable to observe);

$>$ an availability of agrotouristic routes with other touristic routes and soon.

As a result of research of the above mentioned indicators and features, 15 of agrotouristic districts have been separated in the territory of Uzbekistan (see picture). They are allocated to the Ustyurt, Aral Sea, Lower Amudarya, Kyzylkum, Lower Zarafshan, Middle Zarafshan, Nurota, Kashkadarya, GissarZarafshan, Baysun-Bobotogh, Surkhon-Sherobod, Mirzachul, Chirchik-Akhangaran, West Tanshan and Fergana agrotouristic districts. Each agrotouristic district is characterized by the potential and the availability of its own agrarian resources, the availability of conditions for the formation and development of agrotourism, and agricultural specialization [9; pp. 37-38]. It is important to separate the agrotouristic objects in the system of separated districts by methodically [8; pp. 224-226]. For this purpose, the conditions and resources of the agrolandscape plots, which have a set of criteria to allow for a certain type of rest, that the agroturistic specialization is clearly visible in the plots. These sites are also suitable to calculating recreational capacity of the territories [10; pp. 235-236]. 


\begin{tabular}{|c|c|c|c|c|c|c|}
\hline \multirow{4}{*}{ Impact Factor: } & ISRA (India) & $=3.117$ & SIS (USA) & $=0.912$ & ICV (Poland) & $=6.630$ \\
\hline & ISI (Dubai, UAE & $=0.829$ & РИНЦ (Russia & $=0.156$ & PIF (India) & $=1.940$ \\
\hline & GIF (Australia) & $=0.564$ & ESJI (KZ) & $=8.716$ & IBI (India) & $=4.260$ \\
\hline & JIF & $=1.500$ & SJIF (Morocce & $=5.667$ & OAJI (USA) & $=0.350$ \\
\hline
\end{tabular}

The map on the scale of 1:1000000 of agrotouristic districts and Uzbekistan geocomplexes have been created on the basis of generalization according to agrotouristic data and mapping of them. Agrotouristic districts are presented in different colors, displayed in figures and their names are given in the map legend. Also, the map has a brief description on natural geocomplexes and agrotouristic districts.

This map can be used for the organization of touristic routes to visit and monitor the agrotouristic facilities located on the territory of our Republic, as well as in the direction of educational institutions, tourist organizations and firms, hotels and tourists can uses for their activities and interests, as well as advertising the agrotouristic potential and capacities.
1. Despite the widespread development of agrotourism, its scientific and theoretical foundations have not been sufficiently developed. The development of agrotourism is based on certain principles. In this regard, taking into account the various views and ideas of foreign scientists and specialists, the basic principles of agrotourism are defined.

2 . In the mountains, very favorable complexes are the foothill plains, favorable complexes are low mountains and adyrs, medium-high mountains are not favorable, high mountains are unfavorable.

3. On the territory of Uzbekistan, according to the principles and indicators of anthropogenic development, complexity, and tourism opportunities, 15 agrotouristic areas were identified. A 1: 1000000 scale map was created to use of agrotourism.

\section{Conclusions.}

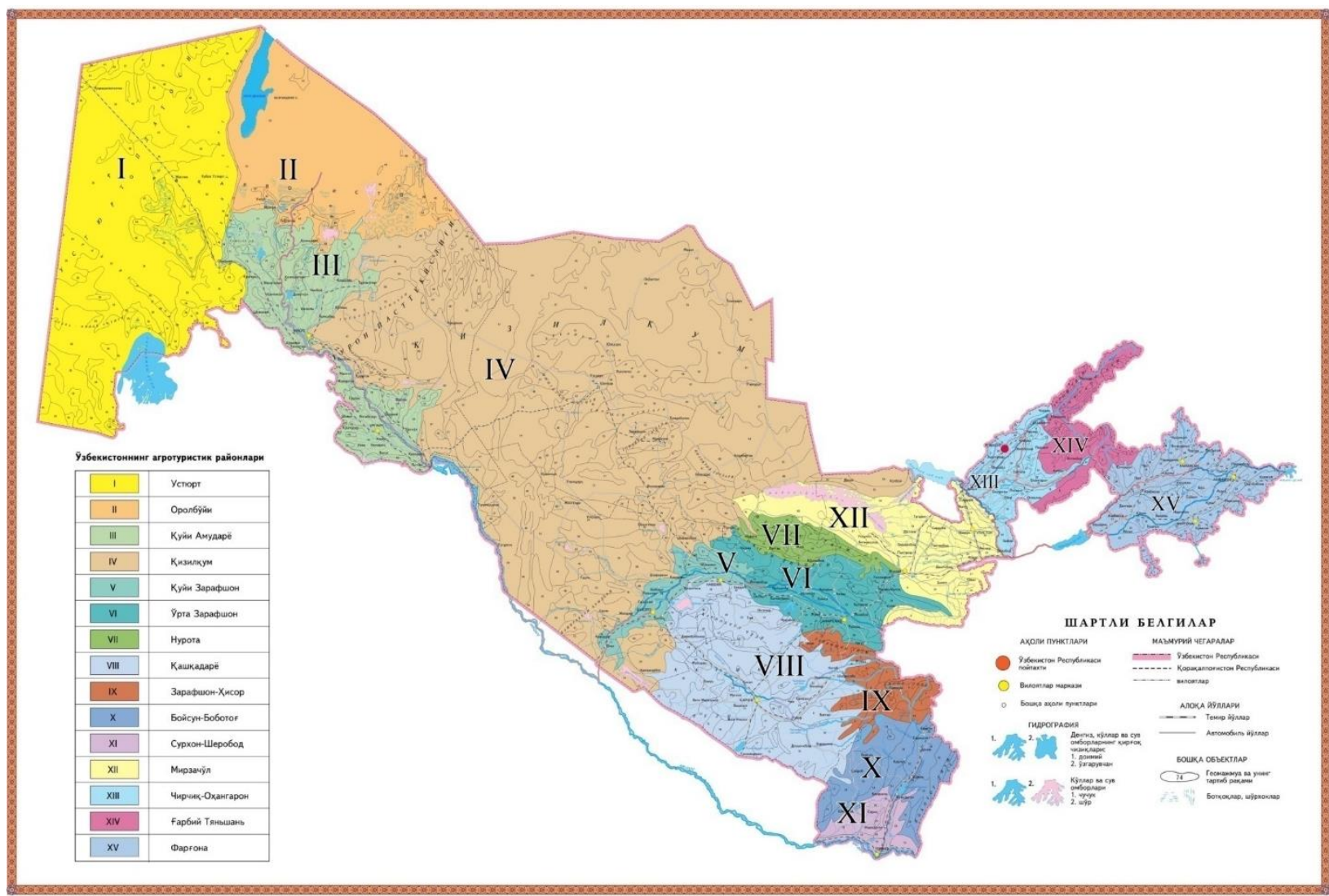

Picture -1. The map of agrotouristic districts of Uzbekistan

\section{References:}

1. Nigmatov, A., \& Yakubjonova, S. (2007). Agrotourism: A New Direction of National Tourism. Agriculture in Uzbekistan, Tashkent, № 9, p.24.
2. Kotlyarov, E. A. (1978). Geography of rest and tourism. (p.238). Moscow.

3. Putrik, Y. S., \& Sveshnikov, V. V. (1986). Rayonirovanie territorii SSSR dlya tseley planovogo turizma. Moskovskiy filial 


\begin{tabular}{llllll} 
& ISRA (India) $=\mathbf{3 . 1 1 7}$ & SIS (USA) $=\mathbf{0 . 9 1 2}$ & ICV (Poland) & $\mathbf{= 6 . 6 3 0}$ \\
Impact Factor: & ISI (Dubai, UAE) $=\mathbf{0 . 8 2 9}$ & PUHЦ (Russia) $=\mathbf{0 . 1 5 6}$ & PIF (India) & $=\mathbf{1 . 9 4 0}$ \\
& GIF (Australia) $=\mathbf{0 . 5 6 4}$ & ESJI (KZ) & $\mathbf{8 . 7 1 6}$ & IBI (India) & $=\mathbf{4 . 2 6 0}$ \\
& JIF & $\mathbf{1 . 5 0 0}$ & SJIF (Morocco) $=\mathbf{5 . 6 6 7}$ & OAJI (USA) & $\mathbf{0 . 3 5 0}$ \\
\hline
\end{tabular}

Geograficheskogo obshchestva SSSR. (pp.313). Moscow.

4. Shomuratova, N. T. (2012). Ecotourism in Uzbekistan and its natural geografic peculiarities. (p.125). Tashkent.

5. Yakubjanova, S. (2008). An agrotourism geography. Information of Uzbekistan geography sociality, Tashkent, № 32, pp.13-15.

6. Yakubjonova, S. (2007). Theoretical aspects of Agrotourism. Tashkent, № 3. pp.53-54.

7. Yakubjonova, S. T. (2012). Agro-industrial potential and territorial differences of Uzbekistan's natural resources. Information of the Geographical Society of Uzbekistan, Tashkent, Volume 39, pp.38-39.

8. Yakubjonova, S. T. (2012). Agrotourism is the factor of national development. NUUz news, Tashkent, № 2, pp.224-226.

9. Yakubjonova, S. T. (2017). Agrotourism is the sourse of ecological and economic opportunities. Ecological Report, Tashkent, № 6, pp.37-38.

10. Yakubjonova, S. T. (2017). Role of Agrotourism in Regional Development and Environmental Protection. NUUz news, Tashkent, № 3/2, pp.235-236. 